\title{
ANALISIS KEABSAHAN PENYADAPAN YANG DILAKUKAN OLEH KOMISI PEMBERANTASAN KORUPSI TANPA IZIN PENGADILAN
}

\author{
Hardy Salim, Monika Kurnia, Nada Dwi Azhari \\ Fakultas Hukum Universitas Tarumanagara
}

\begin{abstract}
ABSTRAK
Tindak pidana korupsi merupakan salah satu extraordinary crime yang pemberantasannya dilakukan secara besar-besaran. Sebagai salah satu upaya pengungkapan dan pencarian alat bukti, penyadapan merupakan salah satu upaya yang efektif dilakukan. Peneliti dalam hal ini bertujuan untuk mengungkap keabsahan daripada penyadapan yang dilakukan oleh KPK tanpa izin pengadilan. Sebagaimana dinyatakan dalam Pasal 28F dan Pasal 28G ayat (1) UUD NRI 1945 yang menyatakan bahwa seseorang berhak memperoleh, menyimpan, dan mengolah dan menyampaikan informasi dengan segala cara yang ada, serta berhak atas perlindungan diri pribadi, keluarga, kehormatan, martabat dan harta benda di bawah kekuasaannya serta berhak atas rasa aman dan perlindungan dari ancaman ketakutan untuk berbuat atau tidak berbuat sesuatu yang merupakan hak asasi manusia, sehingga penyadapan dianggap sebagai salah satu bentuk pembatasan hak asasi manusia. Penyadapan dalam kerangka hukum pidana haruslah dilakukan dengan lawful interception, yang didasarkan pada peraturan yang mengatur secara teknis yang memadai. Apabila aparat penegak hukum melakukan suatu penyadapan tanpa prosedur yang jelas maka akan terjadi penyadapan yang tidak sah atau unlawful interception. Penyadapan yang tidak sah jelas melanggar hak asasi manusia yang mencemari keutuhan kehidupan pribadinya, baik jasmani maupun rohani, yang mana sejatinya tidak boleh menjadi obyek penelitian tanpa persetujuan darinya.
\end{abstract}

Kata kunci:Komisi Pemberantasan Korupsi, lawful interception, unlawful interception.

\section{ABSTRACT}

Corruption is an extraordinary crime which eradicated on a large scale. As one of the efforts to disclose and searching for evidence, interception is an effective effort. The researchers aims to reveal the validity of the interception carried out by the Corruption Eradiction Commission without the court's permission. As stated in Article 28F and Article 28G paragraph (1) of 1945 Constitution of the Republic of Indonesia stated that a person has the right to obtain, store and process and convey informations in all legal ways, and has the right for the protection of personal, family, honour, dignity and properties under his control and the right for the security and protection from the threat of fear to do or not do something. Interception is considered as a form of the limitation of human rights. Interceptions, in the criminal legal framework, must be committed by lawful interception, which is based on regulations that govern technically adequated. If the law enforcement officers do an interception without clear procedures, there will be illegal interception or unlawful interception. Illegal interception clearly violates human rights, which breaks the integrity of his personal life, both 
physically and spiritually, which in fact he cannot be the object of research without his consent.

Keywords: Corruption Eradiction Commission, lawful interception, unlawful interception.

\section{PENDAHULUAN}

Dalam perkembangannya, untuk dapat memenuhi kebutuhan hukum dan mengimbangi perkembangan masyarakat yang berkembang pesat, maka dibentuklah beberapa peraturan perundang-undangan pidana yang bersifat khusus, untuk menyempurnakan ketentuan-ketentuan yang telah ada di dalam Kitab Undang-Undang Hukum Pidana (KUHP). ${ }^{1}$ Salah satu tindak pidana khusus adalah tindak pidana korupsi. ${ }^{2}$

Tindak Pidana Khusus pertama kali dikenal dengan istilah Hukum Pidana Khusus, sekarang diganti dengan istilah Hukum Tindak Pidana Khusus. Hukum Tindak Pidana Khusus berada di luar Hukum Pidana Umum yang mengatur perbuatan tertentu atau berlaku terhadap orang tertentu. Tindak Pidana Khusus merupakan bagian dari hukum pidana. Tidak ada pendefisian Tindak Pidana Khusus secara baku.

Berdasarkan MvT dari Pasal 103 KUHP, istilah "Pidana Khusus" dapat diartikan sebagai perbuatan pidana yang ditentukan dalam perundangan tertentu di luar KUHP. Rochmat Soemitro mendefinisikan tindak pidana khusus sebagai tindak pidana yang diatur tersendiri dalam undang-undang khusus, yang memberikan peraturan khusus tentang tata cara penyidikannya, tuntutannya, pemeriksaanya, maupun sanksinya yang menyimpang dari ketentuan yang dimuat dalam KUHP.

Tindak Pidana Khusus sangat merugikan masyarakat dan negara, maka perlu diadakan tindakan cepat dan perlu diberi wewenang yang lebih luas kepada Penyidik dan Penuntut Umum, hal ini agar dapat mencegah kerugian yang lebih besar. Yang termasuk tindak pidana khusus misalnya Tindak Pidana Korupsi. Undang-undang Pemberantasan Tindak Pidana Korupsi secara khusus mengatur hukum acara sendiri terhadap penegakan hukum pelaku tindak pidana korupsi,

\footnotetext{
${ }^{1}$ Ruslan Renggong, Hukum Pidana Khusus, (Jakarta: Kencana, 2016), hal. 4.

2 Ibid., hal. 58.
} 
secara umum dibedakan dengan penanganan pidana khusus lainnya. Hal ini mengingat bahwa korupsi merupakan extra ordinary crime yang harus didahulukan dibanding tindak pidana lainnya.

Tindak pidana korupsi merupakan salah satu bagian dari Hukum Pidana khusus di samping mempunyai spesifikasi tertentu yang berbeda dengan Hukum Pidana Umum, seperti adanya penyimpangan hukum acara serta apabila ditinjau dari materi yang diatur. Karena itu, tindak pidana korupsi secara langsung maupun tidak langsung dimaksudkan menekan seminimal mungkin terjadinya kebocoran dan penyimpangan terhadap keuangan dan perekonomian negara. Dengan diantisipasi sedini dan semaksimal mungkin penyimpangan tersebut, diharapkan roda perekonomian dan pembangunan dapat dilaksanakan sebagaimana semestinya sehingga lambat laun akan membawa dampak adanya peningkatan pembangunan dan kesejahteraan masyarakat pada umumnya.

Tindak Pidana Korupsi mempunyai hukum acara khusus yang menyimpang dari ketentuan hukum acara pada umumnya. Hukum Acara Pidana yang diterapkan bersifat "lex specialist" yaitu adanya penyimpangan-penyimpangan yang dimaksudkan untuk mempercepat prosedur dan memperoleh penyidikan penuntutan serta pemeriksaan disidang dalam mendapatkan bukti-bukti suatu perkara pidana korupsi dan penyimpangan tersebut dilakukan bukan berarti bahwa hak asasi tersangka/terdakwa dalam tindak pidana korupsi tidak dijamin atau dilindungi, tetapi diusahakan sedemikian rupa sehingga penyimpanganpenyimpangan itu bukan merupakan penghapusan seluruhnya yang terpaksa dilakukan untuk menyelamatkan hak asasi tersebut dari bahaya yang ditimbulkan korupsi. Salah satu ketentuan khusus di dalam Hukum Acara Tindak Pidana Korupsi yang menyimpangi Kitab Undang-Undang Hukum Acara Pidana (KUHAP) ialah dimana hasil penyadapan berfungsi sebagai alat bukti petunjuk sebagaimana ditentukan dalam Pasal 26A Undang-Undang No. 20 Tahun 2001 tentang Perubahan Atas Undang-Undang No. 31 Tahun 1999 tentang Pemberantasan Tindak Pidana Korupsi.

Merujuk pada Pasal 40 Undang-Undang No. 36 Tahun 1999 tentang Telekomunikasi dan Pasal 31 Undang-Undang No. 19 Tahun 2016 tentang perubahan Atas Undang-Undang No. 11 Tahun 2008 tentang Informasi dan 
Transaksi Elektronik, penyadapan pada dasarnya merupakan kegiatan yang dilarang untuk dilakukan. Beberapa peraturan bahkan memberikan ancaman pidana terhadap kegiatan penyadapan. Pengaturan tersebut dalam dilihat pada Pasal 429-433 Wetboek van Strafrecht (untuk bahasa asing dicetak miring) (S. 1915-732) dan Pasal 47 Undang-Undang No. 11 Tahun 2008 tentang Informasi dan Transaksi Elektronik. Kendatipun demikian, tak berarti bahwa penyadapan tidak bisa dilakukan sama sekali. Faktanya, kewenangan untuk melakukan penyadapan diberikan oleh undang-undang kepada beberapa lembaga di Indonesia dengan tujuan yang berbeda-beda. Setidaknya ada 3 tujuan pemberian kewenangan penyadapan, yaitu: (i) Berdasarkan Pasal 20 ayat (3) UndangUndang No. 18 Tahun 2011 tentang Perubahan atas Undang-Undang No. 22 Tahun 2004 tentang Komisi Yudisial, yaitu untuk menjaga dan menegakkan kehormatan, keluhuran martabat serta perilaku hakim ; (ii) Berdasarkan Pasal 31 Undang-Undang No. 17 Tahun 2011 tentang Intelijen Negara, yaitu untuk kepentingan intelijen negara ; dan (iii) Berdasarkan Pasal 12 ayat (1) UndangUndang No. 30 Tahun 2002 tentang Komisi Pemberantasan Tindak Pidana Korupsi, Pasal 26 Undang-Undang No. 31 Tahun 1999 tentang Pemberantasan Tindak Pidana Korupsi, Pasal 31 ayat (1) huruf b Perpu No. 1 Tahun 2002 (Peraturan Pemerintah Pengganti Undang-Undang tentang Pemberantasan Tindak Pidana Terorisme), Pasal 31 ayat (1) Undang-Undang No. 21 Tahun 2007 tentang Pemberantasan Tindak Pidana Perdagangan Orang, Pasal 44 ayat (1) huruf f Undang-Undang No. 8 Tahun 2010 tentang Pencegahan dan Pemberantasan Tindak Pidana Pencucian Uang, Pasal 75 huruf i Undang-Undang No. 35 Tahun 2009 tentang Narkotika, Permen KomInfo No. 11/PER/M.KOMINFO/02/2006 Peraturan Menteri Komunikasi dan Informatika tentang Teknis Penyadapan terhadap Informasi, yaitu untuk kepentingan peradilan pidana.

Sehubungan dengan penyadapan guna kepentingan peradilan pidana, ada beberapa lembaga yang memiliki kewenangan untuk melakukan penyadapan, yaitu Kepolisian Negara Republik Indonesia, Kejaksaan Republik Indonesia, Komisi Pemberantasan Tindak Pidana Korupsi dan Badan Narkotika Nasional. Lebih lanjut, kewenangan untuk melakukan penyadapan yang melekat pada penyidik hanya bisa digunakan untuk mengusut tindak pidana tertentu, yaitu: 
tindak pidana korupsi, tindak pidana terorisme, tindak pidana narkotika, tindak pidana perdagangan orang dan tindak pidana pencucian uang.

Merujuk pada Putusan MK No. No. 006/PUU-I/2003, Putusan No. 012-016019/PUU-IV/2006, dan Putusan MK No. No. 5/PUU-VIII/2010, dapat diketahui bahwa pengaturan mengenai kewenangan penyadapan yang dilakukan oleh KPK tidak mengatur secara khusus dan lengkap jangka waktu dan prosedur mengenai penyadapan, tak ayal penyadapan sering memicu untuk mengatakan timbulnya pelanggaran hak asasi manusia, khususnya hak atas privasi. Tak ayal pula ada prosedur yang harus diikuti dan keadaan yang harus dipenuhi sebelum penyadapan bisa dilakukan. Kendatipun demikian, tidak ada perundang-undangan yang secara tegas memberikan hak kepada mereka yang disadap untuk bisa mempertanyakan apakah penyadapan yang dilakukan sah atau tidak. Padahal apabila merujuk pada Putusan MK No. 21/PUU-XII/2014 mengenai "Masuknya penggeledahan dan penyitaan ke dalam ruang lingkup praperadilan didasarkan pada penafsiran yang dilakukan oleh Mahkamah Konstitusi Republik Indonesia terhadap Pasal 77 huruf a Undang-Undang No. 8 Tahun 1981 tentang Hukum Acara Pidana." Dapat diketahui bahwa tindakan-tindakan tersebut bisa dilakukan oleh penegak hukum, khususnya penyidik, dan membatasi hak asasi manusia, misalnya saja penangkapan, penahanan, penggeledahan maupun penyitaan, bisa diuji keabsahannya menggunakan mekanisme praperadilan.

\section{PERMASALAHAN}

Adapun permasalahan dalam penulisan ini adalah bagaimana keabsahan penyadapan yang dilakukan oleh Komisi Pemberantasan Korupsi tanpa izin pengadilan dalam penegakan tindak pidana korupsi? 
Jenis penelitian yang digunakan yang akan digunakan dalam penelitian ini adalah penelitian hukum normatif, karena dalam penelitian normatif terutama menggunakan bahan-bahan kepustakaan sebagai sumber data penelitian atau disebut juga dengan (Library research), metode yang digunakan untuk mengumpulkan data dari berbagai literatur. ${ }^{3}$

Adapun sumber penelitian yang akan dipergunakan dalam penelitian ini antara lain sebagai berikut Bahan Hukum Primer, yaitu bahan hukum yang bersifat autoritatif, artinya mempunyai otoritas. Bahan Hukum Sekunder yaitu bahan hukum yang tidak mengikat tetapi menjelaskan mengenai bahan hukum primer yang merupakan hasil olahan pendapat atau pikiran para pakar atau ahli yang mempelajari suatu bidang tertentu secara khusus yang akan memberikan petunjuk ke mana peneliti akan mengarah. Bahan nonhukum yaitu bahan hukum yang mendukung bahan hukum primer dan bahan hukum sekunder dengan memberikan pemahaman dan pengertian atas bahan hukum lainnya.

Pengumpulan data dalam penelitian ini akan menggunakan library research (teknik dokumenter), yaitu dikumpulkan dari arsip atau studi pustaka yang ada pada bahan hukum sekunder. Selain itu, wawancara juga salah satu dari teknik pengumpulan data seperti berkas-berkas persidangan dan wawancara dengan pihak terkait yang menunjang teknik dokumenter dalam penelitian ini serta berfungsi untuk memperoleh bahan hukum yang mendukung penelitian jika diperlukan.

Dalam Penelitian ini pendekatan akan lebih ditujukan kepada pendekatan perundang-undangan dan pendekatan historis. Pendekatan perundang-undangan dilakukan dengan menelaah semua undang-undang dan regulasi yang bersangkut paut dengan isu hukum yang sedang ditangani. ${ }^{4}$ Pendekatan perundang-undangan ini digunakan untuk dapat mengumpulkan bahan hukum primer yang menjadi salah satu jenis data penelitian.

Spesifikasi penelitian ini adalah penelitian deskriptif analitis. Dengan penelitian yang bersifat deskriptif analitis, akan dapat dideskripsikan dan

\footnotetext{
${ }^{3}$ Bambang Sunggono, Metode Penelitian Hukum, (Jakarta: PT Raja Grafindo Persada, 2007), hlm. 133.

${ }^{4}$ Ibid., hlm. 133
} 
memberikan data seteliti mungkin mengenai objek yang diteliti. ${ }^{5}$ Analisis data merupakan kegiatan dalam penelitian yang berupaya melakukan kajian atau telaah terhadap hasil pengolahan data yang dibantu dengan teori yang telah didapatkan sebelumnya. Secara sederhana analisis data ini disebut sebagai kegiatan memberikan telaah dan kemudian membuat suatu kesumpulan terhadap hasil penelitian dengan pikiran sendiri dan bantuan teori. ${ }^{6}$

\section{PEMBAHASAN}

Istilah penyadapan atau interception atau wiretapping secara umum berarti mendengarkan secara rahasia pembicaraan orang lain melalui penyadapan telepon atau intersepsi elektronik lainnya. Jeffrey B. Welty menjelaskan bahwa "wiretapping is used to refer to the interception of the context of electronic communications in any format, whether the communication occur via phone, fax email, text messaging, etc."7 Lebih lanjut Amanda Hale menjelaskan bahwa "interception is a condition when a person intercepts a communication in the course of its transmission if, as a result of his interference in the system or monitoring of the transmission if, as a result of the transmission, some or all of the contents are made available, while being transmitted, to a person other than the sender or the intended recipient of the communication." 8 Dari pengertian wiretapping dan interception tersebut dapat diketahui bahwa penyadapan adalah suatu kegiatan intersepsi suatu komunikasi dalam bentuk apapun, baik telepon, email,_pesan singkat, dan lain sebagainya, dan beberapa atau semua konten dilihat saat dikirim kepada seseorang sebagai penerima.

Dalam khazanah hukum dan Hak Asasi Manusia Internasional, penyadapan secara umum dapat dikatakan sebagai perbuatan yang dilarang sebagaimana dimaksud dalam beberapa peraturan. Salah satunya adalah Pasal 12 Universal Dclaration of Human Right 1948 yang menjelaskan bahwa "No one shall be subjected to arbitrary interference with his privacy, family, home or

5 Tunjung Herning Sitabuana (b), "Penyelesaian Masalah Diskriminasi Terhadap Etnis Cina (Studi Tentang Perkembangan Politik Hukum di Bidang Kewarganegaraan Republik Indonesia)", (Ringkasan Disertasi Doktor, Universitas Diponegoro, 2011), hlm. 86.

6 Ibid., hlm. 183.

7 Jeffrey B. Welty, "Prosecution and Law Enforcement Access to Information about Electronic Communication”, Administration of Justice Bulletin, 5 Oktober 2009, hal. 8.

8 Amanda Hale dan John Edwards, "Getting its Taped", Computer and Communications Law Review 2006, hal. 71. 
correspondence, nor to attack upon his honour and reputation. Everyone has the right to protection of the law against such interference attacks." Merujuk pada Pasal ini maka jelas bahwa tidak seorangpun boleh diganggu gugat secara sewenang-wenang dalam urusan pribadi, keluarga, rumah tangga atau hubungan surat-menyurat, tidak juga dilakukan suatu serangan terhadap kehormatan dan reputasinya, karena setiap orang memiliki hak untuk mendapatkan suatu perlindungan hukum atas gangguan seperti itu. Lebih lanjut, hal serupa juga diatur dalam Pasal 17 International Covenant on Civil and Political Rights 1966 (ICCPR) yang berbunyi “(1) No one shall be subjected to arbitrary or unlawfull interference with his privacy, family, home, correspondence, nor to unlawfull attack on his honour and reputation; (2) Everyone has the right to the protection of the law against such interference or attacks.

Merujuk pada Komentar Umum Nomor 16 mengenai Pasal 17 ICCPR yang disepakati oleh Komite Hak Asasi Manusia Perserikatan Bangsa-Bangsa pada persidangan ke dua puluh tiga, 1988 yang memberikan komentar terhadap materi muatan Pasal 17 ICCPR, pada poin 8 dinyatakan bahwa “... bahwa integritas dan kerahasiaan korespondensi harus dijamin secara de jure dan de facto. Korespondensi harus diantarkan ke alamat yang dituju tanpa halangan dan tanpa dibuka atau dibaca terlebih dahulu. Pengamatan, baik secara elektronik maupun lainya, penyadapan telepon, telegram, dan bentuk-bentuk komunikasi lainnya, serta perekaman pembicaraan harus dilarang."9

Kemudian mengenai hak pribadi ini juga diatur dalam Pasal 8 ayat (1) Konvensi Eropa untuk perlindungan Hak Asasi Manusia dan Kebebasan Fundamental 1958 yang menyatakan bahwa "Setiap orang berhak atas penghormatan terhadap kehidupan pribadi atau keluarganya, rumah tangganya dan surat-menyurat." Sehingga berdasarkan beberapa ketentuan sebagaimana telah disebutkan, terlihat secara jelas bahwa pada prinsipnya tindakan penyadapan dalam bentuk apapun merupakan suatu pelanggaran terhadap Hak Asasi Manusia. Hukum internasional menjamin bahwa tidak seorangpun boleh diganggu secara sewenang-wenang terkait urusan pribadi, keluarga, rumah tangga atau hubungan

\footnotetext{
${ }^{9}$ Supriyadi Widodo Eddyono dan Erasmus A. T. Napitupulu, Komentar atas Pengaturan Penyadapan dalam Rancangan KUHAP, (Jakarta: Institute for Criminal Justice Reform, 2013), hal. 7 .
} 
surat-menyuratnya, dan juga tidak boleh dilakukan serangan terhadap kehormatan dan reputasinya.

Secara Internasional, terdapat aturan yang melindungi kehidupan peribadi setiap warga negara, yaitu Right to Privacy. Alat penyadap apapun yang dimiliki oleh pihak tertentu harus dapat emnghargai kehidupan dan aktivitas pribadi setiap warga negara serta harus dihormati dan dilindungi dari kegiatan penyadapan. penyadapan hanya boleh dilakukan untuk kepentingan hukum, bahkan di negara Amerika Serikat dan Negara Barat lainnya, penegak hukum yang ingin melakukan penyadapan harus memiliki izin dari pengadilan terlebih dahulu guna menghindari adanya penyalahgunaan kewenangan penyadapan untuk kepentingan lain.

Di Indonesia itu sendiri, perlindungan atas hak asasi manusia telah diatur secara konstitusional di dalam Konstitusi Negara Indonesia yakni UndangUndang Dasar Negara Republik Indonesia Tahun 1945 (UUD NRI 1945), yang mana telah mengatur secara jelas dan tegas mengenai hak privasi seseorang di mana setiap orang memiliki hak untuk bebas dari rasa takut dan yang lainnya sebagaimana dinyatakan dalam Pasal 28F dan Pasal 28G ayat (1) UUD NRI 1945 yang secara urut menyatakan: "Setiap orang berhak untuk berkomunikasi dan memperoleh informasi untuk mengembangkan pribadi dan lingkungannya, serta berhak untuk memperoleh, memiliki, menyimpan mengolah dan menyampaiakn informasi dengan menggunakan segala jenis saluran yang tersedia"; "Setiap orang berhak atas perlindungan diri pribadi, keluarga, kehormatan, martabat dan harta benda di bawah kekuasaannya serta berhak atas rasa aman dan perlindungan dari ancaman ketakutan untuk berbuat atau tidak berbuat sesuatu yang merupakan hak asasi manusia".

Mengenai hak pribadi tersebut juga diatur di dalam Pasal 14 UndangUndang No. 39 Tahun 1999 tentang Hak Asasi Manusia (UU HAM) yang menyatakan bahwa "Setiap orang berhak untuk berkomunikasi dan memperoleh informasi yang diperlukan untuk mengembangkan pribadi dan lingkungan sosialnya. Setiap orang juga berhak untuk mencari, memperoleh, memiliki, menyimpan, mengolah, dan menyampaikan informasi dengan menggunakan segala jenis sarana yang tersedia." Demikian pula diatur dalam Pasal 21 UU HAM yang menyatakan bahwa "Setiap orang berhak atas keutuhan kehidupan 
pribadinya, baik jasmani maupun rohani, sehingga tidak boleh menjadi obyek penelitian tanpa persetujuan darinya." Kemudian di dalam Pasal 32 UU HAM dijelaskan secara jelas bahwa "Kemerdekaan dan rahasia dalam hubungan suratmenyurat termasuk hubungan komunikasi melalui sarana elektronik tidak boleh diganggu, kecuali atas perintah hakim atau kekuasaan lain yang sah sesuai dengan ketentuan peraturan perundang-undangan."

Lebih lanjut Pasal 40 Undang-Undang No. 36 Tahun 1999 tentang Telekomunikasi (UU Telekomunikasi) menyatakan bahwa "Setiap orang dilarang melakukan kegiatan penyadapan atas informasi yang disalurkan melalui jaringan telekomunikasi dalam bentuk apapun." Penyadapan yang dimaksud dalam Pasal 40 UU Telekomunikasi berdasarkan penjelasan pasal tersebut adalah kegiatan memasang alat atau perangkat tambahan pada jaringan telekomunikasi untuk tujuan mendapatkan informasi dengan cara tidak sah. Pada dasarnya informasi yang dimiliki seseorang adalah hak pribadi yang harus dilindungi sehingga penyadapan harus dilarang.

Kemudian bisa dilihat bahwa di dalam Undang-Undang No. 19 Tahun 2016 jo. Undang-Undang No. 11 Tahun 2008 tentang Informasi dan Transaksi Elektronik (UU ITE) terdapat suatu larangan terhadap intersepsi atau penyadapan yang dilakukan secara tanpa hak dan/atau melawan hukum sebagaimana termaktub dalam Pasal 31 ayat (1) UU ITE yang berbunyi bahwa "Setiap Orang dengan sengaja dan tanpa hak atau melawan hukum melakukan intersepsi atau penyadapan atas Informasi Elektronik dan/atau Dokumen Elektronik dalam suatu Komputer dan/atau Sistem Elektronik tertentu milik Orang lain.”; dan Pasal 31 ayat (2) UU ITE yang berbunyi "Setiap Orang dengan sengaja dan tanpa hak atau melawan hukum melakukan intersepsi atas transmisi Informasi Elektronik dan/atau Dokumen Elektronik yang tidak bersifat publik dari, ke, dan di dalam suatu Komputer dan/atau Sistem Elektronik tertentu milik Orang lain, baik yang tidak menyebabkan perubahan apa pun maupun yang menyebabkan adanya perubahan, penghilangan, dan/atau penghentian Informasi Elektronik dan/atau Dokumen Elektronik yang sedang ditransmisikan."

Sehingga berdasarkan ketentuan-ketentuan dalam peraturan perundangundangan tersebut, maka Indonesia telah menjunjung tinggi perlindungan privasi 
secara konstitusional, yang diatur lebih lanjut dalam berbagai peraturan perundang-undangan. ${ }^{10}$

Walaupun penyadapan secara umum merupakan pelanggaran hak asasi manusia, namun tidak dapat dipungkiri bahwa penyadapan merupakan salah satu metode penyidikan terbaik dalam melakukan penegakan extra ordinary crime. ${ }^{11}$ Dalam kepentingan ini, meskipun secara prinsip segala bentuk penyadapan dilarang menurut hukum internasional, namun terdapat beberapa pengecualian atas larangan penyadapan dalam ranah hukum pidana internasional baik kejahatan inti (core crimes) dan juga diberlakukan pada kejahatan lintas negara terorganisir (transnational organized crime) yang termasuk dalam kejahatan luar biasa (extra ordinary crime), yang meliputi:

1. Kejahatan korupsi (corruption crime);

2. Perdagangan orang (human trafficking);

3. Pencucian uang (money laundering);

4. Perdaganan narkotika (illicit drug trafficking);

5. Penyelundupan senjata (weapon smuggling);

6. Dan lain sebagainya.

Pada kasus extra ordinary crime tersebut dimungkinkan dilakukan penyadapan sepanjang ada pengaturan yang jelas dalam peraturan perundangundangan negara yang terkait. ${ }^{12}$ Penyadapan dalam kerangka Hukum Pidana haruslah dilakukan dengan cara lawful interception, yang berarti suatu penyadapan dan pengawasan terhadap aktifitas komunikasi harus dilakukan secara sah menurut hukum dan dilakukan oleh lembaga pemerintah yang memiliki kewenangan yang ditentukan oleh peraturan tertentu kepada individu maupun kelompok. Penyadapan dapat dikatakan sebagai lawful interception apabila didasarkan pada peraturan yang mengatur secara teknis yang memadai. Apabila aparat penegak hukum melakukan suatu penyadapan tanpa didasarkan pada

\footnotetext{
${ }^{10}$ Supriyadi Widodo Eddyono dan Erasmus A. T. Napitupulu, Op.Cit., hal. 9-10.

11 Ibid.

12 Jawahir Thonthowi, "Penyadapan dalam Hukum Internasional dan Implikasinya terhadap Penegakan Hukum Kejahatan Luar Biasa”, makalah, disampaikan dalam acara Studium General di Fakultas Hukum Universitas Surabaya, Jumat 30 Mei 2014, hal. 7.
} 
kaidah hukum yang berlaku dan atas prosedur yang jelas maka akan terjadi penyadapan yang tidak sah atau unlawful interception. ${ }^{13}$

Kewenangan dalam melakukan penyadapan hanyalah digunakan terbatas untuk mencegah dan mendeteksi dalam hal kejahatan-kejahatan yang sangat serius dengan syarat harus dipergunakan karena metode investigasi kriminal lainnya telah mengalami kegagalan, atau tiada cara lainnya yang dapat digunakan selain penyadapan untuk mendapatkan informasi yang dibutuhkan dan harus ada alasan yang cukup kuat dan dipercaya bahwa dengan penyadapan maka bukti-bukti baru akan ditemukan dan sekaligus dapat digunakan untuk menghukum pelaku pidana. $^{14}$

Di samping itu di beberapa negara, penyadapan dapat juga digunakan dengan dasar kepentingan khusus bagi keamanan negara (interest of national security) dalam rangka penegakan hukum dan stabilitas ekonomi di sebuah negara. Ketentuan pembatas penyadapan bagi aparatur negara di berbagai dunia juga telah demikian berkembang. Penyadapan hanya dapat digunakan dalam kondisi dan prasyarat yang khusus apabila:

1. adanya otoritas resmi yang jelas berdasarkan Undang-Undang yang memberikan izin penyadapan (mencakup tujuan yang jelas dan objektif);

2. adanya jaminan jangka waktu yang pasti dalam melakukan penyadapan;

3. pembatasan penanganan materi hasil penyadapan; dan

4. pembatasan mengenai orang yang dapat mengakses penyadapan dan pembatasan-pembatasan lainnya.

Di Indonesia, terdapat beberapa lembaga negara yang memiliki kewenangan untuk melakukan penyadapan, lembaga-lembaga negara tersebut antara lain:

1. Kepolisian Negara Republik Indonesia, sebagaimana termaktub dalam Peraturan Kepala Kepolisian Negara Republik Indonesia No. 5 Tahun 2010 tentang Tata Cara Penyadapan pada Pusat Pemantauan Kepolisian Negara Republik Indonesia;

2. Badan Narkotika Nasional, sebagaimana termaktub dalam Undang-Undang No. 35 Tahun 2009 tentang Narkotika;

\footnotetext{
${ }^{13}$ Supriyadi Widodo Eddyono dan Erasmus A. T. Napitupulu, Op.Cit., hal. 4.

${ }^{14}$ Ibid.
} 
3. Kejaksaan Agung, sebagaimana termaktub dalam Undang-Undang No. 11 Tahun 2008 tentang Informasi dan Transaksi Elektronik;

4. Komisi Pemberantasan Tindak Pidana Korupsi, sebagaimana termaktub dalam Undang-Undang No. 30 Tahun 2002 tentang Komisi Pemberantasan Tindak Pidana Korupsi;

5. Badan Intelijen Negara, sebagaimana termaktub dalam Undang-Undang No. 17 Tahun 2011 tentang Intelijen Negara.

Dari semua lembaga negara yang memiliki kewenangan untuk melakukan penyadapan, lembaga negara yang paling kontroversial dalam melakukan kewenangannya untuk melakukan penyadapan adalah Komisi Pemberantasan Tindak Pidana Korupsi. Walaupun menurut Penasihat Komisi Pemberantasan Korupsi, Abdullah Hehamahua wewenang penyadapan merupakan hal yang tidak boleh hilang dari Komisi Pemberantasan Korupsi karena dalam pelaksanaannya, hampir lebih dari 50\% kasus korupsi yang berasal dari penyuapan terungkap melalui penyadapan. Walaupun pada akhirnya terkait kewenangan Komisi Pemberantasan Tindak Pidana Korupsi (KPK) sebagaimana termaktub dalam Undang-Undang No. 30 Tahun 2002 tentang Komisi Pemberantasan Tindak Pidana Korupsi (UU KPK) memunculkan adanya polemik dalam masyarakat. Hal ini dikarenakan UU KPK tidak menjelaskan prosedur dan standar pelaksanaan penyadapan, UU KPK hanya menyatakan bahwa KPK dalam melakukan penyelidikan dan penyidikan berwenang untuk melakukan penyadapan atau merekam pembicaraan. Dari penjelasan tersebut maka KPK dapat secara bebas mengintervensi segala aktivitas pribadi setiap individu/manusia, terutama mengintervensi kerahasiaan hubungan komunikasi pribadi dan rentan menimbulkan pelanggaran terhadap HAM.

Penjelasan Pasal 31 ayat (1) Undang-Undang No. 1 Tahun 2008 tentang Informasi dan Transaksi Eletronik menjelaskan bawa yang dimaksud dengan intersepsi atau penyadapan adalah "kegiatan untuk mendengarkan merekam, membelokkan, mengubah, menghambat, dan/atau mencatat transmisi Informasi Elektronik dan/atau Dokumen Elektronik yang tidak bersifat publik, baik menggunakan jaringan kabel komunikasi maupun jaringan nirkabel seperti pancaran elektromagnetis atau radio frekuensi." Lebih lanjut, Undang-Undang 
No. 30 Tahun 2002 tepatnya pada Pasal 12 ayat (2) dinyatakan bahwa dalam melaksanakan tugas penyelidikan, penyidikan, penuntutan sebagaimana dimaksud dalam Pasal 6 huruf c, Komisi Pemberantasan Korupsi berwenang melakukan penyadapan dan merekam pembicaraan. Meninjau kedua pasal tersebut, kewenangan KPK untuk melakukan penyadapan yang diberikan oleh UndangUndang No. 30 Tahun 2002 tidak menjelaskan dengan rinci mengenai mekanisme serta batasan atas pelaksanaan kewenangan penyadapan tersebut.

Padahal apabila kita melihat pengaturan di peraturan perundang-undangan lainnya seperti Peraturan Pemerintah Pengganti Undang-Undang No. 1 Tahun 2002 tentang Pemberantasan Tindak Pidana Terorisme sebagaimana telah disahkan dengan Undang-Undang No. 15 Tahun 2003 telah diatur secara rinci tata cara pelaksanaan dalam Pasal 31 yang berbunyi:

(1) Berdasarkan bukti permulaan yang cukup sebagaimana dimaksud dalam pasal 26 ayat (4), penyidik berhak:

a. Membuka, memeriksa, dan menyita surat dan kiriman melalui pos atau jasa pengiriman lainnya yang mempunyai hubungan dengan perkara tindak pidana terorisme yang sedang diperiksa;

b. Menyadap pembicaraan melalui telepon atau alat komunikasi lain yang diduga digunakan untuk mempersiapkan, merencanakan, dan melakukan tindak pidana terorisme.

(2) Tindakan penyadapan sebagaimana dimaksud dalam ayat (1) huruf b, hanya dapat dilakukan atas perintah ketua pengadilan negeri untuk jangka waktu paling lama 1 (satu) tahun.

(3) Tindakan sebagaimana dimaksud dalam ayat (1) dan ayat (2) harus dilaporkan atau dipertanggungjawabkan kepada atasan penyidik.

Ketidakjelasan pengaturan mengenai tata cara pelaksanaan penyadapan yang dilakukan oleh KPK khususnya tanpa izin pengadilan menyebabkan penggunaan rekaman dan penyadapan yang dilakukan oleh KPK sebagai alat bukti dalam persidangan tanpa sepengetahuan dan seiring orang yang bersangkutan bertentangan dengan due process of law dan melanggar hak privasi seseorang. Aturan yang jelas tidak semata-mata demi perlindungan privasi seseorang, lebih dari itu adalah untuk menegakkan due process of law. Marc Webber Tobias dan Roy Davis Petersen dalam "Pre-Trial Criminal Procedure: $a$ Survey of Constitutional Rights" mendefinisikandue process of law sebagai jaminan konstitusi bahwa setiap warga negara berhak atas perlindungan terhadap 
tindakan pemerintah yang sewenang-wenang. ${ }^{15}$ Tanpa adanya persetujuan atau pemberitahuan, maka hasil rekamannya haruslah dianggap tidak sah (illegal) karena kedudukannya sama dengan penyadapan yang dilakukan secara illegal.

Lebih lanjut merujuk pada pendapat Chairul Huda dalam rangka memberikan keterangan sebagai ahli dalam Putusan MK No 012-016- 019/PUUIV/2006 yang menyatakan bahwa dalam melakukan penyadapan juga meneladan kepada berbagai ketentuan lain dalam hukum acara pidana (KUHAP), misalnya dalam melakukan penyitaan dan penyidikan harus mendapat izin dari Ketua Pengadilan Negeri. Sama halnya dengan penyadapan, juga terdapat sesuatu yang “diambil”, yaitu "informasi". Sesuai dengan prinsip "information is power" dalam masyarakat, maka informasi yang disadap juga menjadi sangat penting bagi yang bersangkutan, dan boleh jadi mempunyai nilai yang lebih tinggi apabila dibandingkan dengan uang atau barang lainnya.

Kewenangan Penyadapan yang dimiliki oleh KPK boleh saja dilakukan, namun harus bisa diatur sedemikian rupa sehingga tidak melanggar hak asasi manusia seseorang, sehingga diperlukan suatu pengaturan yang khusus dan bersifat siu generis mengenai batasan dan mekanisme penyadapan, selain itu perlu juga dibentuk lembaga pengawas, sehingga jelas yang mana objek dan subjek dari penyadapan, guna menghindari kesadaran prosedur penyadapan. Penyadapan harus dilakukan dengan alasan yang jelas dan sudah memiliki bukti permulaan yang cukup, agar tidak serta merta dilakukan penyadpaan terhadap seseorang, hingga akhirnya mencederai rasa keadilan dan hak asasi manusia seseorang. Walaupun penyadapan merupakan salah satu faktor penting dalam pengungkapan kasus korupsi, namun menurut Direktur Pusat Kajian Antikourpsi Universitas Gadjah Mada, Zainil Arifin Muchtar, penyadapan akan menjadi sangat tidak etis apabila dilakukan untuk tujuan pengungkapan kasus yang tidak pernah dipermasalahkan karena dapat mengganggu hak privasi seseorang.

Lebih lanjut menurut Wakil Ketua Komisi Pertahanan dan Luar Negeri Dewan Perwakilan Rakyat, Agus Gumiwang menyatakan bahwa negara Korea Selatan dan Australia yang terkenal sebagai negara antikorupsi yang relatif bersih

\footnotetext{
${ }^{15}$ RZK, "Aturan Penyadapan, Perlindungan atau Ancaman Bagi Pengguna Telekomunikasi”, http://www.hukumonline.com/berita/baca/lt4b34d3deb69c6/penyadapan, 25 Desember 2009, dibuka pada 29 Agustus 2018 pukul 19.32 WIB.
} 
memiliki pengaturan yang jelas tentang penyadapan. Hal tersebut guna menghindari adanya penggunaan penyadapan untuk suatu kepentingan di luar pengungkapan kasus korupsi sehingga melanggar hak asasi manusia dan orang merasa terganggu karena penyadapan tidak sesuai dengan aturan yang ada.

Di Amerika Serikat, otoritas yang mengurusi izin penyadapan adalah United States Foreign Intelligence Surveillance Court (untuk bahasa asing dicetak miring) yang dibentuk berdasarkan United States Foreign Intelligence Surveillance Act (untuk bahasa asing dicetak miring) (FISA), yang diundangkan pada tahun 1978 dan telah diamandemen sebanyak tiga kali. Menariknya di Amerika Serikat diundangkan Electronic Communicaion Privacy Act (untuk bahasa asing dicetak miring) pada tahun 1986, yang mengatur perlindungan tidak hanya terhadap komunikasi verbal, tetapi juga komunikasi elektronik seperti sinyal, tulisan, gambar dan suara dengan cara menetapkan syarat yang ketat seperti harus ada surat perintah.

Sampai saat ini baru Indonesia baru melakukan tindakan sebatas menyisipkan pasal-pasal penyadapan dalam undang-undang yang bersifat umum. Berangkat dari kondisi ini, Indonesia sudah saatnya membenahi regulasi penyadapan yang berlaku sekarang. Dengan dasar hukum yang jelas, maka kinerja aparat penegak hukum ketika melakukan penyadapan tidak lagi diragukan legitimasinya. Model pembenahan regulasinya bisa mengadopsi best practice di negara-negara lain. Namun yang pasti, prinsip-prinsip yang harus diakomodir dalam pembenahan regulasi penyadapan nanti adalah bagaimana upaya penegakan hukum tidak terhambat tetapi tetap menghormati hak asasi warga negara Indonesia, termasuk hak privasi.

Berdasarkan hal tersebut, maka tindakan yang dilakukan oleh penyelidik maupun penyidik terkait dengan tindakan mengambil atau menyimpan (penyitaan) informasi yang diperoleh dan berkaitan dengan perkara pidana yang sedang diperiksa atau dapat dijadikan sebagai alat bukti, harus memperoleh izin dari Ketua Pengadilan Negeri. Pentingnya izin pengadilan karena penyadapan merupakan upaya paksa yang dilakukan penyelidik maupun penyidik untuk menemukan alat bukti dan upaya paksa tersebut telah mengintervensi HAM, terutama hak privasi terkait kerahasian hubungan komunikasi pribadi. Karena 
penyadapan sebagai upaya paksa telah mengintervensi HAM maka pengadilan berwenang untuk melakukan kontrol terhadap HAM dari segala upaya paksa yang berkaitan dengan proses hukum pidana. Sesuai dengan dasar dibentuknya suatu pengadilan yaitu untuk melindungi HAM terkhusus dalam proses hukum pidana. 


\section{PENUTUP}

\section{A.KESIMPULAN}

Penyadapan merupakan tindakan yang dilarang karena melanggar hak asasi manusia yang lain sebAgaimana dinyataan bahwa setiap manusia berhak atas penjagaan informasi pribadinya dan keamanan atas dirinya ataupun barang yang ada padanya, sehingga tindakan mendengarkan atau melihat aktifias yang dilakukannya haruslah atas kehendak dan izin dari objek yang didengarkan informasi pribadinya. Pada kasus extra ordinary crime dimungkinkan dilakukan penyadapan sepanjang ada pengaturan yang jelas dalam peraturan perundangundangan negara yang terkait, atau dengan lawful interception. Kewenangan dalam melakukan penyadapan hanyalah digunakan terbatas untuk mencegah dan mendeteksi dalam hal kejahatan-kejahatan yang sangat serius dengan syarat harus dipergunakan karena metode investigasi kriminal lainnya telah mengalami kegagalan, atau tiada cara lainnya yang dapat digunakan selain penyadapan untuk mendapatkan informasi yang dibutuhkan dan harus ada alasan yang cukup kuat dan dipercaya bahwa dengan penyadapan maka bukti-bukti baru akan ditemukan dan sekaligus dapat digunakan untuk menghukum pelaku pidana. Tindakan yang dilakukan oleh penyelidik maupun penyidik terkait dengan tindakan mengambil atau menyimpan (penyitaan) informasi yang diperoleh dan berkaitan dengan perkara pidana yang sedang diperiksa atau dapat dijadikan sebagai alat bukti, harus memperoleh izin dari Ketua Pengadilan Negeri.

\section{SARAN}

Kewenangan Penyadapan yang dimiliki Komisi Pemberantasan Korupsi sebaiknya ditinjau kembali apakah benar melanggar hak asasi manusia khususnya hak privasi seseorang atau tidak, sehingga dapat memberikan kepastian hukum bagi masyarakat. Kemudian membuat pengaturan yang jelas mengenai mekanisme dan prosedur penyadapan yang dimiliki oleh Komisi Pemberantasan Korupsi untuk dapat memenuhi due process of law, baik dengan menggunakan izin pengadilan atau menggunakan prosedur lain yang telah digunakan oleh negaranegara antikorupsi yang bersih lainnya, sehingga dapat membuat kewenangan penyadapan yang dimiliki oleh Komisi Pemberantasan Korupsi ini dapat menjadi lawful interceptio 


\section{DAFTAR PUSTAKA}

\section{Buku}

Ruslan Renggong. Hukum Pidana Khusus. Jakarta: Kencana, 2016.

Supriyadi Widodo Eddyono dan Erasmus A. T. Napitupulu, Komentar atas Pengaturan Penyadapan dalam Rancangan KUHAP, Jakarta: Institute for Criminal Justice Reform, 2013.

\section{Artikel}

Amanda Hale dan John Edwards. "Getting its Taped". Computer and Communications Law Review 2006.

Jawahir Thonthowi. "Penyadapan dalam Hukum Internasional dan Implikasinya terhadap Penegakan Hukum Kejahatan Luar Biasa". makalah, disampaikan dalam acara Studium General di Fakultas Hukum Universitas Surabaya, Jumat 30 Mei 2014.

Jeffrey B. Welty. "Prosecution and Law Enforcement Access to Information about Electronic Communication". Administration of Justice Bulletin, 5 Oktober 2009.

\section{Peraturan Perundang-Undangan}

Indonesia. Undang-Undang Dasar Negara Republik Indonesia Tahun 1945.

Indonesia. Undang-Undang Nomor 31 Tahun 1999 tentang Pemberantasan Tindak Pidana Korupsi (Lembaran Negara Republik Indonesia Tahun 1999 Nomor 140, Tambahan Lembaran Negara Republik Indonesia Nomor 387).

Indonesia. Undang-Undang Nomor 39 Tahun 1999 tentang Hak Asasi Manusia (Lembaran Negara Republik Indonesia Tahun 1999 Nomor 165, Tambahan Lembaran Negara Republik Indonesia Nomor 3886).

Indonesia. Undang-Undang Nomor 20 Tahun 2001 tentang Perubahan Atas Undang-Undang Nomor 31 Tahun 1999 tentang Pemberantasan Tindak Pidana Korupsi (Lembaran Negara Republik Indonesia Tahun 2001 Nomor 134, Tambahan Lembaran Negara Republik Indonesia Nomor 4150).

Indonesia. Undang-Undang Nomor 11 Tahun 2008 tentang Informasi dan Transaksi Elektronik (Lembaran Negara Republik Indonesia Tahun 2008 Nomor 58, Tambahan Lembaran Negara Republik Indonesia Nomor 4843).

Indonesia. Undang-Undang Nomor 19 Tahun 2016 tentang Perubahan atas Undang-Undang Nomor 11 Tahun 2008 tentang Informasi dan Transaksi 
Elektronik (Lembaran Negara Republik Indonesia Tahun 2016 Nomor 251, Tambahan Lembaran Negara Republik Indonesia Nomor 5952).

Indonesia. Undang-Undang Nomor 36 Tahun 1999 tentang Telekomunikasi (Lembaran Negara Republik Indonesia Tahun 1999 Nomor 154).

\section{Internet}

RZK. "Aturan Penyadapan, Perlindungan atau Ancaman Bagi Pengguna Telekomunikasi".

http://www.hukumonline.com/berita/baca/lt4b34d3deb69c6/penyadapan, 25 Desember 2009. 